\section{Vlasenko I. Semko T., Palamarchuk V.}

\title{
THE INFLUENCE OF THE COMPOSITION OF BACTERIAL STARTER CULTURES ON THE MATURATION PROCESS AND THE DUALITY OF HARD RENNET CHEESE
}

Об'єктом дослідження є закваски, що використовуються у виробництві твердих сичужних сирів.

Одним з найбільш проблемних місиь є підбір кількості та складу бактеріальних заквасок для виробництва твердих сирів з низькою температурою другого нагрівання.

В ході дослідження використовувалися методи аналізу та синтезу - при вивченні джерел наукової літератури з тематики дослідження; методи лабораторних (біохімічних та мікробіологічних) досліджень - при проведенні визначень оптимального складу бактеріальних заквасок; органолептичні методи - при визначенні якості готової продукції; методи математичної статистики - для обробки результатів дослідження.

У процесі дослідження показано, що для покращення зсідання молока, яке пройшло високотемпературне оброблення, потрібно вносити у молочну суміш подвійну дозу хлористого кальиію і сичужного ферменту та 0,1\% бактеріальної закваски. Окрім того суміш необхідно витримувати 12 годин при $10-12{ }^{\circ} \mathrm{C}$ для покращення сиропридатності молока.

В результаті проведених досліджень встановлено, що при збільшенні загальної кількості бактеріальної закваски відбувається підвищення кислотності молока перед зсіданням, скорочення тривалості вимішування зерна після другого нагрівання і підвищення кислотності сироватки на всіх стадіях технологічного процесу.

Найбільш вдалими слід вважати зразки сирів, виготовлених з закваскою, до складу якої входило 1,5\% комплексу мезофільних лактобактерій і 0,3 \% термофільних лактобащил Lb. acidophilus, використання яких забезпечує формування значно вищих органолептичних показників сичужних сирів.

Використання високоефективних бактеріальних заквасок, підвищений вміст вологи в продукті і визрівання продукту при підвищеній температурі дозволяють одержати сир із скороченим терміном визрівання - 25-30 діб.

Таким чином, в результаті досліджень встановлено оптимальні технологічні параметри, які дозволять отримувати сичужні сири з низькою температурою другого нагрівання високої якості.

Ключові слова: тверді сири, бактеріальні закваски, заквашувальні культури, молочнокислі бактеріі, молокозгортаючі ферменти.

Received date: 06.12.2019

Accepted date: 24.12 .2019

Published date: 28.02.2020
Copyright (C) 2020, Vlasenko I., Semko T., Palamarchuk V. This is an open access article under the CC BY license (http://creativecommons.org/licenses/by/4.0)

\section{Introduction}

The quality of rennet cheese largely depends on the bacterial starter. It is found that cheeses can be obtained using special bacterial starter cultures and regulating the technological parameters of their production. One of the most important characteristics of lactic acid bacteria that are used in the production of cheese is their proteolytic activity. The action of proteolytic enzymes of starter microorganisms makes a significant contribution to the hydrolysis of milk proteins, contributes to the formation of organoleptic and rheological properties of cheese. The decisive role is played by the composition of proteinases and peptidases of microorganisms, their specificity and activity. The scientific approach to the composition of starter cultures used in the production of cheese should take into account the activity of proteases, as well as their role in the formation of indicators inherent in a particular type of cheese. Thus, the composition of the starter cultures used is crucial for obtaining high-quality cheese with certain properties.

A study of the problems of production of hard cheeses has been devoted to a number of works by domestic and foreign scientists. So, in [1], modern technologies for the production of hard cheeses are considered. In [2], the ripening parameters in the production of functional rennet cheeses are considered. The author in [3] investigated the prospects for industrial production of cheese with probiotic properties.

Therefore, it is urgent to develop the composition of mixtures of starter bacterial cultures for the production of solid rennet cheeses with a low temperature of second heating and justification of the parameters for their use.

Thus, the object of research is the composition of bacterial starter cultures for the production of solid rennet cheese. And the aim of research is determination of the optimal composition of bacterial starter cultures for the production of hard cheeses. 


\section{Methods of research}

In the study, the following scientific methods are used: - analysis and synthesis method - when studying the sources of scientific literature on research topics;

- methods of laboratory (biochemical and microbiological) studies - when determining the quality indicators of raw milk and finished products, their microbial contamination;

- methods of mathematical statistics - for processing research results.

\section{Research results and discussion}

To improve the physico-chemical properties of milk as a medium for the development of microflora of starter cultures and milk-curdling enzymes, its maturation is carried out. For the purpose of ripening milk after pasteurization, chilled milk to a temperature of $20-22{ }^{\circ} \mathrm{C}$ is added with $0.5-0.8 \%$ lactic acid starter and kept at this temperature for no more than 1 hours. Then cooled to $10{ }^{\circ} \mathrm{C}$ and stored for $8-12$ hours. This regime creates the conditions for the development of lactic acid lactococci, which are introduced with starter culture. After ripening, milk needs additional pasteurization, its maximum acidity in this case is $22-23{ }^{\circ} \mathrm{C}$. Considering that during pasteurization of milk the balance between different forms of calcium salts is disturbed, prevents coagulation with rennet, calcium salts are added to milk in the form $40 \%$ calcium chloride solution.

In the production of rennet cheese, a milk clot is formed under the action of milk-laden enzymes, but the composition of the used starter cultures is of great importance for the formation of the organoleptic and physicochemical properties inherent in a certain type of cheese. Lactic acid bacteria are the main component of microflora necessary for the production of any kind of natural cheese. Their main action is the production of enzymes, under the influence of which deep biochemical changes in the cheese mass occur, lead to the fact that it acquires a specific taste, aroma, texture and pattern are formed. In addition, lactic acid bacteria create conditions that inhibit or accelerate the development of harmful and pathogenic microflora. In the process of cheese production, they accelerate the syneresis of milk clots due to acidification of the medium as a result of fermentation of lactose to lactic acid. The stock and output of soft rennet cheeses are significantly affected by the indicators of the starter culture used for biotechnological processing of milk, as well as the pasteurization of milk. For soft bifid cheese, the use of synbiotic complexes is recommended, including:

- mixed cultures of mesophilic lactic acid lactococ-

cus $L$. lactis $+L$. diacetilactis (or pure cultures of Str. Thermophilus), pure (B. animalis) or mixed (B. bifi$d u m+B$. longum $+B$. breve) bifidobacteria cultures;

- fructose (the concentration of fructose is $0.1 \%$ of the weight of fermented milk) as a stimulant for the growth of bifidoflora in milk.

The compositions of three symbiotic complexes have been developed:

1) starter culture FD DVS CH N-19, including mixed cultures of mesophilic lactic acid lactococcus L. lactis + + L. diacetilactis, + starter culture LD DVS Bb-12, including pure cultures of $B$. animalis, + fructose;
2) starter culture Liobac $M C L-24$, including mixed cultures of mesophilic lactic acid lactococcus $L$. lactis $+L$. diacetilactis, + starter culture Liobac BIFI, including mixed cultures of $B$. bifidum $+B$. longum $+B$. breve, + fructose;

3) starter culture Liobac $M E$-36, including pure cultures of Str. thermophilus, + Liobac BIFI starter culture, including mixed cultures of B. bifidum $+B$. longum $+B$. breve, + fructose.

The main representatives of the necessary microflora for cheeses with a low temperature of the second heating are lactococci (according to the old nomenclature, mesophilic lactic streptococci) and aroma-forming leuconostocs $[4,5]$. They include acid-forming lactococci (Str. Lactis, Str. Cremoris) and aromatizing (Str. Citrovorus, Str. Paracitrovorus, Str. Diacetilactis, Str. Acetoinicus). They are the main components of starter bacterial concentrates.

In addition to lactococcus and leukostasis, mesophilic lactobacilli can be added to the composition of starter cultures to accelerate the ripening of cheeses or inhibition of harmful gas-forming bacteria [6-8].

An example of this kind of bacterial compositions is the composition of the bacterial concentrates BK-Uglich-7K, BK-Uglich-5A, Bioantibut produced by the experimental biofactory in Uglich (Russia).

Lactobacilli weakly attack casein. However, lactococci stimulate their development in milk by the formation of low molecular weight nitrogenous compounds during the hydrolysis of casein and other growth factors, a decrease in $\mathrm{pH}$ and Eh. In studies [9], it is noted that with the combined use of lactococcus and $L b$. casei cultures biomass yield increases by $39 \%$, proteolytic activity against $\alpha_{\mathrm{s} 1}$-casein increases by almost 6 times.

Lactobacilli have greater proteolytic activity compared to lactococci $[10,11]$. For example, when exposed to milk proteins, enzymes that are secreted by thermophilic bacilli $L b$. acidophilus and $L b$. Helveticum. The content of such an amino acid as tyrosine among protein proteolysis products is, respectively, 1.5 and 1.6 times higher than during cultivation of Lactococcus lactis subsp. lactis [9, 12]. In the last decade, thermophilic lactic acid bacilli are widely used in the composition of starter cultures [13].

In addition to the increased, compared with lactococcus, proteolytic activity of lactobacilli, they have an antagonistic effect on technologically harmful microflora and pathogenic bacteria [14]. As part of the starter cultures, together with lactococcus, strains of the mesophilic bacillus Lb. plantarum are used, producing the antibiotic lactoline, which inhibits the bacteria of the group of Escherichia coli and butyric acid bacteria.

Antagonistic effect in a number of representatives of harmful microflora has Lb. acidophilus. Due to the production of antibiotics, acidophilus and lactocidin $L b$. acidophilus inhibits the development of salmonella, shigella, staphylococci and other pathogenic microorganisms.

In 1990, Ukraine developed the technology of cheese with a low temperature of the second heating, which eliminates the use of nitrates [15]. To replace the chemical treatment of milk with sodium nitrate or potassium, the biological treatment of milk by Lb. Acidophilus is used, which has provided the suppression in milk and cheese of technically harmful microflora, which causes deficiencies in cheeses such as early and late bloating.

Due to its probiotic characteristics, acidophilus bacillus allows the production of high-quality cheese with a reduced ripening time of 1.5 days, while the product 
withstands a long shelf life without any flaws in taste and consistency. The biological advantage of $L b$. Acidophilus in comparison with other lactic acid bacilli has the ability to take root in the human intestine.

Lb. Acidophilus has a high acid-forming ability and is used as part of starter cultures for hard cheeses for a deeper deoxidation of whey at the stage of processing of cheese grain.

The most significant changes in the production of cheese occur during the processes of coagulation of milk proteins and the separation of whey from a clot. Therefore, in the production of cheeses, an important role is played by lactosefree preparations, which, along with the coagulation of milk proteins, stimulate the development of lactic acid bacteria in the starter culture, which turn lactose into lactic acid. And their enzymes carry out further hydrolysis of all components of the cheese mass.

Thus, the milk-curdling enzyme is one of the most important components in the production technology of natural cheeses, because:

- affects the nature of the formation of a clot;

- formation and formation of cheese grains;

- separation of whey, loss of protein and fat with whey;

- directionally regulates proteolytic processes in cheese during its maturation.

The basis of this process is the primary proteolytic reaction, which causes casein to coagulate under the influence of a milk-curdling enzyme. As a result of this reaction, peptides are formed, which are substrates in other proteolytic reactions that occur when cheese is ripened by the action of enzymes of lactic acid microflora of bacterial starter cultures. The production of high quality cheeses is closely related to the intensity and direction of these enzymatic transformations of the cheese mass, as a result of which the finished product acquires a taste and aroma characteristic of each type of cheese.

Rennet, which contains two active components, chymosin and pepsin, which composition is predominantly chymosin, is widely used as a milk-curdling drug. It has high specificity for milk protein and has minimal proteolysis ability. Rennet chymosin induces an initial schedule for the paracasein-calciumphosphate complex to large molecular weight fragments.

Extracellular and intracellular enzymes of lactic acid bacteria mainly affect the decomposition products of paracasein. With the combined action on the proteins of milk of rennet and bacterial enzymes, the effectiveness of each of them increases. But the leading role in the enzymatic breakdown of proteins in the curd mass belongs to lactic acid bacteria. Therefore, to accelerate the ripening of cheeses, it is necessary to use starter cultures, which include cultures with high proteolytic activity.

Coagulation of milk proteins is one of the most important steps in the cheese production process. Coagulation cheese milk proteins or rennet coagulation of casein is irreversible and includes two stages - enzymatic and coagulation. The hydrolysis of phosphoamidase bonds (-N-P-) in casein takes place under the influence of rennet. In this case, the amount of active hydroxyl groups $(\mathrm{OH})$ in the phosphoric acid residue increases, and the hydrogen atom joins the amino acid residue with the formation of paracasein, which easily gives off hydrogen and attaches calcium. Considering that calcium has two valencies, it binds two hydroxyl groups and forms «calcium bridges» between paracasein molecules. Thus, under the action of rennet, aggregation of particles of paracasein and clot formation occurs.
The structure, consistency, pattern and other indicators of cheese depend on the speed of obtaining rennet, its structural-mechanical and synergetic properties. Further changes in protein during cheese maturation occur under the action of proteinases and starter microflora peptidases [16].

The technological parameters of the coagulation of milk proteins determine the direction of the production process of a certain type of cheese with characteristic organoleptic properties, which are laid in a cheese-making bath and are formed during the ripening of cheese. The aging process is closely related to the intensity and direction of enzymatic processes involving all components of the cheese mass. The most important of these are protein proteolysis and hydrolysis of the lipid components of the cheese mass. Enzymatic transformations occur with the formation of numerous compounds, form a specific taste and aroma of solid rennet cheese with a low temperature of the second heating.

Thus, in order to accelerate the maturation of rennet cheeses and protect them from the negative influence of extraneous microflora, as well as to increase the safety of cheeses for the health of consumers, it is advisable to use lactic acid sticks as part of bacterial starter cultures, which allow creating new technologies and expanding the assortment of cheeses.

Among the lactic acid bacteria used in the production of cheese, lactic acid lactococci of the Lactococcus lactis ssp species, diacetilactis, L. lactis ssp. lactis, L. lactis ssp. Cremoris are of great importance. They are part of most starter cultures and bacterial preparations used for the production of cheeses with a low temperature of the second heating.

To study the effect of bacterial starter culture on the process of making rennet cheese with a low temperature of second heating from milk, which underwent preliminary high-temperature (HT) and ultra high-temperature (UHT) processing, and determine the main technological factors under the influence of which the quality of the finished product is formed, the starter is made from a concentrate of mesophilic lactococci. The main complex starter culture of mesophilic lactococcus includes acid and aroma-forming cultures such as Lactococcus lactis subsp. lactis, Lactococcus lactis subsp Lactococcus lactis subsp diacetilactis, Leuconostoc lactis. As an additional starter culture, thermophilic lactic acid bacilli of the species Lactobacillus acidophilus (residual race) are used. Aromatizing microorganisms differ from acid forming in their ability to ferment citric acid and its salts to form $\mathrm{CO}_{2}$. The use of bacterial starter cultures without aromatizing microorganisms leads to the production of cheese without a pattern with high acidity and brittle consistency. In the absence of acid-forming cultures, a decrease in the activity of starter culture occurs, the formation of an overdeveloped pattern and the enhanced development of harmful microflora in cheese.

Fermentation of milk that has undergone high-temperature processing is carried out with certain differences compared to the existing technological process, which is widely used in the production of natural rennet cheeses with a low temperature of the second heating. After a hightemperature treatment at a temperature of $(81 \pm 1){ }^{\circ} \mathrm{C}$ with a soak of $25 \mathrm{~s}$ and a UHT treatment of $(120 \pm 1)^{\circ} \mathrm{C}$ with a soak of $5 \mathrm{~s}$, the milk is cooled to a temperature of $66^{\circ} \mathrm{C}$ for $10 \mathrm{~s}$, after which it was further cooled to $10^{\circ} \mathrm{C}$, that is, to the ripening temperature of milk. Chilled milk is mixed for 5 minutes to evenly distribute the constituent components 
of the milk. And also made $0.1 \%$ of the main bacterial starter culture, made from a concentrate, which includes Lactococcus lactis subsp. lactis, Lactococcus lactis subsp cremoris, Lactococcus lactis subsp diacetilactis, Lenconostoc lactis, and left to mature at 12 hours. After 12 hours, the milk is heated to a fermentation temperature of $34{ }^{\circ} \mathrm{C}$ and a different ratio of the main and additional starter cultures is introduced:

- $0.7 \%$ main and $0.1 \%$ additional;

- $1.5 \%$ primary and $0.3 \%$ additional;

- $2.0 \%$ main and $0.5 \%$ additional.

As a result of the studies, it is found that with an increase in the total amount of bacterial starter culture, there is an increase in the acidity of milk before coagulation, a decrease in the duration of mixing of the grain after the second heating, and an increase in the acidity of whey at all stages of the technological process. The results of changes in technological factors depending on the type of high-temperature processing and the composition of the used starter cultures after statistical processing are given in Table 1.

Rennet cheeses with a low temperature of the second heating obtained from milk that passed HT and UHT, upon reaching 30 days of age, are investigated by organoleptic indicators according to GOST 7616-85. The main attention is paid to such indicators as consistency (highest score 25 points), taste and smell (highest score -45 points). Other indicators, such as color and pattern, conditionally put higher scores.

The results of an organoleptic study of rennet cheeses made from milk that has undergone high-temperature pro- cessing, and with different amounts of bacterial yeast introduced according to the main organoleptic indicators are given in Table 2 .

An organoleptic evaluation shows that cheeses made using the main and additional starter culture in the ratio of $(0.7+0.1) \%$ and $(1.5+0.3) \%$ to the volume of milk has higher rates compared to cheeses made from starter culture crops in the ratio $(2.0+0.5) \%$.

Thus, limit and average doses of starter cultures are selected (basic from 0.7 to $2 \%$; additional 0.1 to 0.5 ).

A study of the process of lactic acid fermentation of milk, which underwent HT and UHT treatment, fermented with mesophilic lactobacilli in an amount of from 0.7 to $1.5 \%$ and thermophilic lactobacilli of the $L b$. acidophilus type in an amount of from 0.1 to $0.3 \%$. This processing ensures the formation of rennet cheese of the highest grade with organoleptic properties that meet the requirements of the standard for the quality of rennet cheese with a low temperature of the second heating.

The most successful should be considered samples of cheeses made from starter culture, which included $1.5 \%$ of the complex of mesophilic lactobacilli and $0.3 \%$ of thermophilic lactobacilli $L b$. acidophilus, the use of which ensures the formation, according to the conclusions of tasters, of higher organoleptic characteristics of rennet cheese.

The process of cheese ripening, the formation of its composition and organoleptic properties are significantly affected by such technological factors as the temperature of the second heating of cheese grain and the salting process, which provides a mass fraction of salt in the cheese.

Characterization of the technological process of viral fermentation of milk after high temperature fermentation with different types

Table 1 of bacterial starter cultures $(n=3, P \geq 0.95)$

\begin{tabular}{|c|c|c|c|c|c|c|}
\hline \multirow{3}{*}{ Indicators } & \multicolumn{6}{|c|}{ The ratio of primary and secondary starter cultures, \% } \\
\hline & \multicolumn{2}{|c|}{$0.7+0.1$} & \multicolumn{2}{|c|}{$1.5+0.3$} & \multicolumn{2}{|c|}{$2.0+0.5$} \\
\hline & HT & UHT & HT & UHT & HT & UHT \\
\hline Acidity of milk before coagulation, ${ }^{\circ} \mathrm{T}$ & 18.0 & 18.0 & 18.0 & 18.0 & 18.0 & 18.0 \\
\hline Coagulation milk temperature, ${ }^{\circ} \mathrm{C}$ & 33 & 33 & 33 & 33 & 33 & 33 \\
\hline Cheese sample & 2.75 & 3.82 & 2.70 & 3.83 & 2.75 & 3.80 \\
\hline The amount of introduced enzyme, g & 3.5 & 5.5 & 3.5 & 5.5 & 3.5 & 5.5 \\
\hline Amount of introduced $\mathrm{CaCl}_{2}$, g & 80 & 80 & 80 & 80 & 80 & 80 \\
\hline $\begin{array}{l}\text { Duration, min.: } \\
\text { - coagulation; } \\
\text { - ripening of the clot and processing of cheese grain to a second heating }\end{array}$ & $\begin{array}{l}30 \\
25\end{array}$ & $\begin{array}{l}30 \\
25\end{array}$ & $\begin{array}{l}30 \\
25\end{array}$ & $\begin{array}{l}30 \\
25\end{array}$ & $\begin{array}{l}30 \\
25\end{array}$ & $\begin{array}{l}30 \\
25\end{array}$ \\
\hline Amount of pasteurized water added, for deoxidation, \% of the amount of processed milk & 10 & 10 & 10 & 10 & 15 & 15 \\
\hline Temperature of the second heating, ${ }^{\circ} \mathrm{C}$ & 42 & 42 & 42 & 42 & 42 & 42 \\
\hline Duration of mixing the grain after the second heating, min & 40 & 60 & 35 & 55 & 30 & 50 \\
\hline $\begin{array}{l}\text { Average values of whey titroacidity, }{ }^{\circ} \mathrm{T} \text { : } \\
\text { - before the second heating; } \\
\text { - after making pasteurized water }\end{array}$ & $\begin{array}{c}15.0 \\
13.31 \\
\end{array}$ & $\begin{array}{l}15.20 \\
13.51 \\
\end{array}$ & $\begin{array}{c}15.0 \\
13.22 \\
\end{array}$ & $\begin{array}{l}15.31 \\
13.43 \\
\end{array}$ & $\begin{array}{r}15.0 \\
13.41 \\
\end{array}$ & $\begin{array}{c}15.40 \\
14.0 \\
\end{array}$ \\
\hline $\begin{array}{l}\text { Mass fraction of moisture in cheese, \%: } \\
\text { - after pressing; } \\
\text { - at } 30 \text { days of age }\end{array}$ & $\begin{array}{l}50.72 \\
46.31\end{array}$ & $\begin{array}{l}51.23 \\
47.09\end{array}$ & $\begin{array}{l}50.51 \\
46.21\end{array}$ & $\begin{array}{l}51.29 \\
46.89\end{array}$ & $\begin{array}{l}50.78 \\
46.31\end{array}$ & $\begin{array}{l}51.41 \\
47.36\end{array}$ \\
\hline Mass fraction of fat in the dry matter of cheese of 30 days of age, \% & 41.2 & 41.6 & 41.0 & 41.3 & 40.2 & 40.8 \\
\hline Mass fraction of salt, \% & 1.76 & 2.32 & 1.82 & 2.22 & 1.89 & 2.19 \\
\hline $\mathrm{pH}$ after pressing, units & 5.43 & 5.25 & 5.32 & 5.22 & 5.20 & 5.15 \\
\hline $\mathrm{pH}$ at 30 days of age, units & 5.24 & 5.18 & 5.19 & 5.14 & 5.15 & 5.08 \\
\hline
\end{tabular}

Note: the values of the mass fraction of moisture in the cheese after pressing from all baths are tried to get close to each other by changing the processing time of cheese grain after the second heating; indicate the value of HT - (120 \pm 1$)^{\circ} \mathrm{C}$ with a shutter speed of $5 \mathrm{~s}$; UHT $-(120 \pm 1){ }^{\circ} \mathrm{C}$ with a shutter speed of $5 \mathrm{~s}$ 
Organoleptic evaluation of rennet cheese from milk after high-temperature processing at a different ratio of bacterial starter ( $n=3, P \geq 0.95$ )

\begin{tabular}{|c|c|c|c|c|c|c|}
\hline $\begin{array}{c}\text { The ratio of primary } \\
\text { nd secondary start culture, \% }\end{array}$ & Taste and smell & 5соге & Consistency & 5соге & $\begin{array}{l}\text { Total } \\
\text { score }\end{array}$ & Grade \\
\hline \multicolumn{7}{|c|}{ Cheeses made from milk after HT processing } \\
\hline $0.7+0.1$ & Well-defined cheesy, sour, faint taste & 38.3 & Good & 24.0 & 92.3 & High \\
\hline $1.5+0.3$ & Well expressed cheesy, sour & 39.3 & Good & 24.0 & 93.3 & High \\
\hline $2.5+0.5$ & Well-defined cheesy, overly sour, faint bitterness & 37.0 & Good & 24.0 & 91.0 & High \\
\hline \multicolumn{7}{|c|}{ Cheeses made from milk after UHT processing } \\
\hline $0.7+0.1$ & Sour, weak bitterness & 38.0 & Good & 24.0 & 92.0 & High \\
\hline $1.5+0.3$ & Well expressed cheesy, sour & 39.0 & Good & 24.0 & 93.0 & High \\
\hline $2.0+0.5$ & Sour, bitter & 35.3 & Satisfactory, smeared & 23.0 & 88.3 & High \\
\hline
\end{tabular}

It is established that the influence of these factors on the quality of the finished product is closely interconnected. Acceleration of ripening of hard cheeses by technological methods is quite limited. On the one hand, an increase in temperature conditions of processing and moisture content in cheese, a decrease in active acidity and salt concentration intensifies the formation of organoleptic indicators. On the other hand, these factors contribute to the creation of conditions for the development of extraneous microflora, cause certain shortcomings and worsen the safety and quality of cheeses.

Thus, when substantiating the technology for the production of rennet cheeses, it is necessary to take into account the influence of each of the factors and establish optimal technological parameters that will make it possible to obtain rennet cheeses with a low temperature of second high-quality heating.

\section{Conclusions}

In the process of research it is shown that to improve the coagulation of milk, which has undergone high-temperature processing, it is necessary:

- add to the milk mixture for the manufacture of cheeses

a double dose of calcium chloride and rennet and $0.1 \%$

bacterial sourdough;

- withstand 12 hours at $10-12{ }^{\circ} \mathrm{C}$ to improve the cheese ability of milk.

As a research result of the effect of the composition of bacterial starter cultures on the aging process, safety and quality of cheese, the following is established. With an increase in the total amount of bacterial starter culture, an increase in the acidity of milk before coagulation occurs, a decrease in the duration of grain kneading after a second heating, and an increase in the acidity of whey.

The use of highly effective bacterial starter cultures, the increased moisture content in the product and the maturation of the product at elevated temperatures make it possible to obtain cheese with a reduced ripening time of 25-30 days.

\section{References}

1. Danyliuk, A. Yu., Verbelchuk, T. V. (2016). Suchasni tekhnolohii vyrobnytstva tverdykh syriv. Stan ta perspektyoy oyrobnytstva, pererobky $i$ vykorystannia produktsii toarynnytstva. KamianetsPodilskyi: Zvoleiko D. H., 144-146.

2. Didukh, N. A., Molokopoi, L. O. (2010). Obgruntuvannia parametriv vyzrivannia pry vyrobnytstvi tverdykh sychuzhnykh syriv funktsionalnoho pryznachennia. Kharchova nauka $i$ tekhnolohiia, 2 (11), 22-26.
3. Tkachenko, N. A., Lanzhenko, L. O. (2015). Tverdi syry z probiotychnymy vlastyvostiamy: perspektyvy promyslovoho vyrobnytstva. Prohrama ta materialy 75 Naukovoi konferentsii Naukovopedahohichnoho skladu akademii Odeskoi natsionalnoi akademii kharchooykh tekhnolohii. Odesa: ONAKhT, 120-121.

4. Zhukova, L. L., Bobrov, A. V., Karpova, T. I. (2002). Intensifikaciia processa sozrevaniia tverdykh syrov. Syrodelie i maslodelie, 5, 6-7.

5. Ramanauskas, R. (2004). Voprosy povysheniia kachestva sychuzhnykh syrov. Pererabotka moloka, 4, 6-8.

6. Müller, B. (1981). Milchprodukte hergestllt mit Lactobacillus acidophilus. Deutche Molkerei - Zeitung, 102 (48), 1615-1617.

7. Sienkiewicz, T., Hansen, R. (1988). Lu proteolytischen Vorgängen bei der Reifung von Labkäse (Teil 1). Milchforschung Milchproxis, 4, 103-105

8. Madkor, S. A., Tong, P. S., El Soda, M. (2000). Ripening of Cheddar Cheese with Added Attenuated Adjunct Cultures of Lactobacilli. Journal of Dairy Science, 83 (8), 1684-1691. doi: http://doi.org/10.3168/jds.s0022-0302(00)75037-5

9. Usinzinger, W., Sebastiani, H. (1993). Proteolytische Aktivität thermophiler Lactobacillen. Deutsche Molkeni Ztg, 114 (3), 49-51.

10. Cachon, R., Jeanson, S., Aldarf, M., Divies, C. (2002). Characterisation of lactic starters based on acidification and reduction activities. Le Lait, 82 (3), 281-288. doi: http://doi.org/10.1051/ lait:2002010

11. Smirnov, E. A., Sorokina, N. P. (2008). Bakterialnye zakvaski i koncentraty v biotekhnologii syrodeliia. Syrodelie i maslodelie, 6, 14-16.

12. Chopard, M.-A., Schmitt, M., Perreard, E., Chamba, J.-F. (2001). Aspect qualitative de l'activité protéolytique des lactobacillus thermophiles utilisés en fabrication de fromages à pâte pressée cuite. Le Lait, 81 (1-2), 183-194.

13. Bondarchuk, Z. V., Fedin, F. A. (2008). Syr «Zorianii». Molochnoe delo, 4, 47

14. Niku-Paavola, M.-L., Laitila, A., Mattila-Sandholm, T., Haikara, A. (1999). New types of antimicrobial compounds produced by Lactobacillus plantarum. Journal of Applied Microbiology, 86 (1), 29-35. doi: http://doi.org/10.1046/j.1365-2672.1999.00632.x

15. Kolesnykova, S. S. (200). Pat. No. 27144 UA. Sposib vyrobnytstva tverdoho syru z nyzkoiu temperaturoiu druhoho nahrivannia. No. 95104480. declareted: 12.10.1995; published: 28.02.2000; Biul. No. 1, 3

16. Kriger, A. V., Belov, A. N. (2010). Vliianie fermentnikh kompozicii na proteoliz v syrakh. Syrodelie i maslodelie, 3, 38-40.

Vlasenko Iryna, MD, Professor, Head of Department of Commodity Science, Expertise and Commercial Business, Vinnytsia Institute of Trade and Economics of Kyiv National University of Trade and Economics, Ukraine, e-mail: vlasenkoivol@gmail.com, ORCID: http:// orcid.org/0000-0001-9995-2025

Semko Tetiana, PhD, Associate Professor, Department of Tourism Hotel and Restaurant Business, Vinnytsia Institute of Trade and Economics of Kyiv National University of Trade and Economics, Ukraine,e-mail:semko1965@ukr.net, ORCID: http://orcid.org/00000002-1951-5384

Palamarchuk Vladyslav, PhD, Associate Professor, Department of Commodity Science, Expertise and Commercial Business, Vinnytsia Institute of Trade and Economics of Kyiv National University of Trade and Economics, Ukraine, e-mail:kupc1989@gmail.com, ORCID:http:// orcid.org/0000-0002-7478-9521 